\title{
Electroporation-transformation System for Coryneform Bacteria by Auxotrophic Complementation
}

\author{
Yasurou Kurusu, Mami KaInuma, Masayuki InuI, Yukie SatoH \\ and Hideaki YuKAwA \\ Tsukuba Research Center, Mitsubishi Petrochemical Co., Ltd. \\ Inashiki, Ibaraki 300-03, Japan
}

Received August 8, 1989

\begin{abstract}
We evaluated electroporation as an alternative system for genetic exchange for one of the coryneform bacteria, Brevibacterium flavum MJ233.

The maximum number of transformants, $6 \times 10^{4}$ cells, was obtained when cells were cultured with Penicillin $G(1 \mathrm{U} / \mathrm{ml})$ and harvested at the middle-log phase. Electroporation was done using $12.5 \mathrm{kV} / \mathrm{cm}$ of pulse field strength, $1 \times 10^{10}$ cells, and $1 \mu \mathrm{g}$ of plasmid DNA.

Other coryneform bacteria, Brevibacterium lactofermentum ATCC 13869, Corynebacterium glutamicum ATCC 31830, and B. stationis IFO 12144 were also transformed by electroporation.

Electroporation has the advantage that intact cells can be used as host cells without the need for protoplast formation and regeneration. Moreover, minimal medium can be used, so auxotrophic complementation of the transformants is possible.
\end{abstract}

Coryneform bacteria are Gram-positive microorganisms, wide-spread in nature, that have been used for industrial fermentation, such as L-glutamic acid, ${ }^{1)}$ L-lysine, ${ }^{2)}$ and other amino acid production.

Brevibacterium flavum $\mathrm{MJ} 233,{ }^{3}$ ) belonging to the coryneform group, has some useful characteristics including the ability to metabolize ethanol as a sole carbon source, a rapid growth rate, and no autolysis under starvation condition. Therefore, we have been studying $B$. flavum MJ233 for the production of chiral chemicals such as L-aspartic acid, ${ }^{3)} \mathrm{L}$ isoleucine, ${ }^{4)}$ and L-malic acid. ${ }^{5}$

There have been no extensive studies on the practical improvement of these bacteria, since molecular genetic studies have not progressed for lack of an efficient genetic transformation system. However, some reports about the genetic transformation system have been reported. ${ }^{6-10)}$ These transformation methods for coryneform bacteria can be classified into two protocols: 1) transfection of protoplast cells $^{73}$ and 2) addition of plasmid DNA to protoplast cells in the presence of polyethyleneglycol (PEG). ${ }^{6,8-10}$ ) These two methods are still associated with problems including low transformation efficiency, difficulties of protoplasting, and a period of more than 10 days required to obtain transformants. In these problems, the most serious is the necessity for regeneration, because the medium for regeneration is too highly enriched to select transformants by auxotrophic complementation.

To overcome these problems, we used electroporation for the transformation of coryneform bacteria. Electroporation brings about the uptake of DNA into living cells because it induces transient pores in their outer membranes. This technique has been commonly used to transfer DNA into a variety of eucaryotic cells ${ }^{11}$ and several bacteria. ${ }^{12-14)}$ However, only one report has been published on the transformation of coryneform bacteria by electroporation. ${ }^{15}$ ) In this report, the transformation of osmotically sensitive Corynebacterium glutamicum was examined by high voltage-electroporation using nutrient-enriched medium for regeneration.

In this study, we demonstrate the possibility for the selection of transformants on minimal medium by auxotrophic complementation, 
and have used this electroporation method on other coryneform bacteria, B. lactofermentum, $C$. glutamicum, and B. stationis.

\section{Materials and Methods}

Bacterial strains and plasmids. Bacterial strains and plasmids are described in Table I. Cured strains were obtained from B. flavum MJ233, B. stationis IFO 12144, B. lactofermentum ATCC 13869, and C. glutamicum ATCC 31830 by incubation with novobiocin $(50 \mu \mathrm{g} / \mathrm{ml})^{16}$ and used as recipient strains. A tryptophan auxotrophic mutant of B. flavum MJ233 was isolated by a modification of the method of Kase and Nakayama. ${ }^{171}$

Plasmid isolation. Plasmid DNA was isolated by the alkaline lysis procedure. ${ }^{18}$ The plasmid pHSG $398^{19}$ carrying the chloramphenicol resistance gene from $E$. coli was purchased from Takara Shuzo Co., Ltd. (Japan)

Plasmid construction. To isolate fragments of pBY $503^{20}$ from $B$. stationis IFO 12144 that were capable of autonomous replication, pBY 503 and pHSG 398 were digested separately with $K p n l$, then mixed and ligated. The ligated DNA was then used to transform B. flavum MJ233 to a chloramphenicol-resistant phenotype $(\mathrm{Cm})$. Ten $\mathrm{Cm}^{r}$ transformants were characterized and all were found to carry the same recombinant plasmid containing the $6.0-\mathrm{kb}$ $K p n I$ fragment derived from pBY503 and the 2.2-kb fragment of pHSG398. This plasmid was named pCRY3.

To construct the pCRY3-trp, miniF-trp ${ }^{21)}$ was digested with $S a l$ I and XhoI to obtain a $7.7-\mathrm{kb}$ fragment containing the $E$. coli tryptophan operon. This DNA fragment was treated with $\mathrm{S} 1$ nuclease to produce blunt ends, ligated to the BamHI linker, and the resulting DNA fragments were religated to the unique BamHI site of pCRY3 to form pCRY3-trp (Table I).

Culture conditions. Minimal medium ${ }^{22}$ [glucose, $20 \mathrm{~g}$; $\left(\mathrm{NH}_{4}\right)_{2} \mathrm{SO}_{4}, 7 \mathrm{~g}$; urea, $2 \mathrm{~g} ; \mathrm{K}_{2} \mathrm{HPO}_{4}, 0.5 \mathrm{~g} ; \mathrm{KH}_{2} \mathrm{PO}_{4}, 0.5 \mathrm{~g}$; $\mathrm{MgSO}_{4} \cdot 7 \mathrm{H}_{2} \mathrm{O}, 0.5 \mathrm{~g} ; \mathrm{FeSO}_{4} \cdot 7 \mathrm{H}_{2} \mathrm{O}, 6 \mathrm{mg} ; \mathrm{MnSO}_{4} \cdot 4$ $6 \mathrm{H}_{2} \mathrm{O}, 6 \mathrm{mg}$; biotin, $200 \mu \mathrm{g}$; thiamine- $\mathrm{HCl}, 200 \mu \mathrm{g}$; and deionized water to 11 (adjusted to $\mathrm{pH} 7.5$ with $\mathrm{NaOH}$ ) was used for selection of transformant by auxotrophic complementation.

All coryneform strains were routinely grown in AR medium $^{22}$ [ $1 \mathrm{~g}$ of yeast extract and $1 \mathrm{~g}$ of casamino acids were added to minimal medium]. In selective media, $5 \mu \mathrm{g} / \mathrm{ml}$ of chloramphenicol or $25 \mu \mathrm{g} / \mathrm{ml}$ of streptomycin were added. Cultivation was done with shaking $(220 \mathrm{rpm}$, $70 \mathrm{~cm}$ stroke) at $33^{\circ} \mathrm{C}$ for B. flavum MJ233 and at $30^{\circ} \mathrm{C}$ for the other coryneform strains.

Transformation by electroporation. The basic protocol was based on the Gene Pulser's Manual (BioRad Lab. Richmond, CA). A $0.5 \%$ inoculum from an overnight culture of coryneform bacteria in AR medium was inoculated into $100 \mathrm{ml}$ of the same medium and grown with shaking ( $220 \mathrm{rpm}, 70 \mathrm{~cm}$ stroke). When the O.D.610 of the culture reached 0.5 , Penicillin $\mathrm{G}$ (Pen $\mathrm{G})(1 \mathrm{U} / \mathrm{ml})$ was added. After $2 \mathrm{hr}$ of incubation at $33^{\circ} \mathrm{C}$, the cells were harvested from $10 \mathrm{ml}$ of culture broth by centrifugation at $4^{\circ} \mathrm{C}$ for $10 \mathrm{~min}$ at $6,000 \mathrm{rpm}$ and were washed twice with $6 \mathrm{ml}$ of chilled deionized water, and once with $6 \mathrm{ml}$ of chilled transformation buffer ( $\mathrm{HG}$ buffer), which contained $1 \mathrm{~mm} \quad N$-2-hydroxyethyl-piperazine- $N^{\prime}$-2-ethanesulfonic acid (HEPES) and $10 \%$ glycerol, $\mathrm{pH} \mathrm{7.4.} \mathrm{The}$ cells were suspended in $\mathrm{HG}$ buffer to a final volume of

Table I. Bacterial Strains and Plasmids

\begin{tabular}{|c|c|c|}
\hline Strain or plasmid & Phenotype or description & Source of reference \\
\hline \multicolumn{3}{|l|}{ Strains } \\
\hline B. flavum MJ233 & Harbors pBY 502 & $(20)$ \\
\hline B. flavum $\mathrm{MJ} 233 \mathrm{trp}$ & $\begin{array}{l}\text { Tryptophan auxotroph isolated from } \\
\text { NTG-mutagenized } \mathrm{MJ} 233\end{array}$ & This study \\
\hline B. lactofermentum & ATCC 13869 harbors pAM330 & $(25)$ \\
\hline B. stationis & IFO 12144 harbors pBY 503 & $(20)$ \\
\hline C. glutamicum & ATCC 31830 harbors pCG4 & $(6)$ \\
\hline \multicolumn{3}{|l|}{ Plasmids } \\
\hline pCRY3 & $\begin{array}{l}\text { B. flavum-E. coli shuttle vector } \\
\mathrm{Cm}^{\mathrm{r}}\end{array}$ & $(20)$ \\
\hline pCRY3-trp & $\begin{array}{l}\text { pCRY } 3 \text { carrying } E \text {. coli trp operon } \\
\qquad \mathrm{Cm}^{5}\end{array}$ & This study \\
\hline pAJ655 & $\begin{array}{l}\text { B. lactofermentum-E. coli shuttle vector } \\
\qquad \mathrm{Cm}^{\mathrm{r}}, \mathrm{Ap}^{\mathrm{r}}\end{array}$ & $(25)$ \\
\hline pCG4 & $\mathrm{Sm}^{2}$ & (6) \\
\hline MiniF-trp & MiniF carrying $E$. coli trp operon & (21) \\
\hline
\end{tabular}


T80 $\mu$ l (approximately $5 \times 10^{10}$ cells $/ \mathrm{ml}$ ), mixed with plasmid DNA $(1 \mu \mathrm{g})$ dissolved in $20 \mu \mathrm{l}$ of $\mathrm{HG}$ buffer and kept on ice for 2 or $3 \mathrm{~min}$. This suspension was transferred to a Gene Pulser cuvette $(0.2-\mathrm{cm}$ interelectrode-gap cuvette) and $0.8 \mathrm{ml}$ of $\mathrm{HG}$ buffer was put onto the cell suspension gently to avoid mixing the two liquid layers. After one pulse, the cell suspension was diluted by a 5 -fold volume of $\mathrm{AR}$ medium and incubated at $30^{\circ} \mathrm{C}$ for $1 \mathrm{hr}$ without shaking. Portions were spread on AR medium agar plates containing $5 \mu \mathrm{g} / \mathrm{ml}$ of chloramphenicol $(\mathrm{Cm})$ for cells transformed by pCRY3 and pAJ655, or $25 \mu \mathrm{g} / \mathrm{mI}$ of streptomycin (Sm) for pCG4. The pulse field strengths used were 6.25 kilo volts per centimeter $(\mathrm{kV} / \mathrm{cm})$ and/or $12.5 \mathrm{kV} / \mathrm{cm}$.

\section{Results and Discussion}

\section{Cell preparation and electroporation conditions}

Several reports have appeared concerning the high effectiveness of electroporation to obtain transformants using log phase cells. ${ }^{13,14}$ Transformation efficiency might be closely related to the physiological condition of the cell wall.

High voltage electroporation, such as 10 $\mathrm{kV} / \mathrm{cm}$ or $12.5 \mathrm{kV} / \mathrm{cm}$, increased the transformation efficiency in some kinds of bacteria. ${ }^{14,23)}$ These phenomena might indicate that transformation efficiency is also closely related to the physical change of the cell wall.

Therefore, we investigated factors that might affect transformation by physiological and/or physical changes of the cell wall such as growth phase, effectiveness of Pen $G$, and pulse field strength.

1) Effects of growth phase. To attain high transformation efficiency using $B$. flavum MJ233, we examined the effects of the growth phase. The maximum number of transformants per $\mu \mathrm{g}$ of pCRY3 DNA was obtained at the middle-log phase. However, either at the very early or the late log phase, the number of transformants was decreased by approximately one-tenth (data not shown). Therefore, the cells harvested at the middle-log phase were used for the following experiments.

2) Effects of Penicillin $G$ concentration. Generally, a known inhibitor of cell wall synthesis, Pen G, is used to form protoplasts of coryneform bacteria. $^{6,24,25)}$ To increase the
Table II. EfFects on Transformation Efficiency of Penicillin G Addition to Medium

The number of transformants
under each Pen $\mathrm{G}$ conc.
a

Table III. EfFects of Various Electroporation Buffers on Transformation EFFICIENCY

\begin{tabular}{cc}
\hline Buffers & $\begin{array}{c}\text { Number of } \\
\text { transformants }\end{array}$ \\
\hline $272 \mathrm{mM} \mathrm{sucrose}^{a} 7 \mathrm{mM} \mathrm{KH}_{2} \mathrm{PO}_{4}$ & $8.7 \times 10^{2}$ \\
$272 \mathrm{mM} \mathrm{sucrose} 7 \mathrm{mM} \mathrm{KH}_{2} \mathrm{PO}_{4}$, & $6.3 \times 10^{3}$ \\
$1 \mathrm{mM} \mathrm{MgCl}$ & \\
$272 \mathrm{mM} \mathrm{sucrose}_{2} 7 \mathrm{mM} \mathrm{KH}_{2} \mathrm{PO}_{4}$, & $6.9 \times 10^{2}$ \\
$1 \mathrm{mM} \mathrm{MgCl}_{2}, 15 \%$ glycerol & \\
$272 \mathrm{mM} \mathrm{sucrose} 7 \mathrm{mM} \mathrm{KH}{ }_{2} \mathrm{PO}_{4}$, & $1.7 \times 10^{3}$ \\
$15 \%$ glycerol & \\
$1 \mathrm{~mm} \mathrm{HEPES}, 10 \%$ glycerol $(\mathrm{HG})$ & $6.3 \times 10^{4}$ \\
$10 \%$ glycerol & $1.5 \times 10^{4}$
\end{tabular}

a Electroporation was done at a cell concentration of $5 \times 10^{10} / \mathrm{ml}$, amount of $1 \mu \mathrm{g}$ of pCRY 3 DNA, and a pulse field strength of $12.5 \mathrm{kV} / \mathrm{cm}$. The number of surviving cells after the pulse was $1 \times 10^{9}$ for each buffer.

transformation efficiency, the effects of the addition of Pen $G$ to medium as a pretreatment of cells were examined (Table II). Addition of $1 \mathrm{U} / \mathrm{ml}$ of Pen $\mathrm{G}$ increased the transformation efficiency by approximately 2 orders of magnitude compared with the control.

3) Effects of pulse field strength and electroporation buffer. The above results were obtained using $6.25 \mathrm{kV} / \mathrm{cm}$ of pulse field strength. As shown in Tables II and III, the effects of the pulse field strength on electroporation efficiency were examined. A pulse field strength of $12.5 \mathrm{kV} / \mathrm{cm}$ had one order of magnitude higher efficiency than $6.25 \mathrm{kV} / \mathrm{cm}$.

As shown in Table III, several electropo- 
(a)

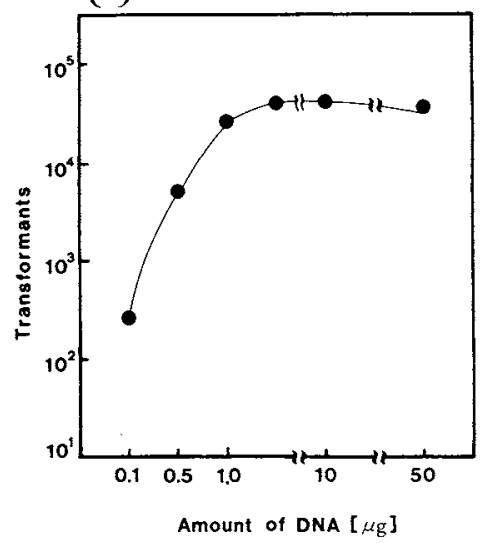

(b)

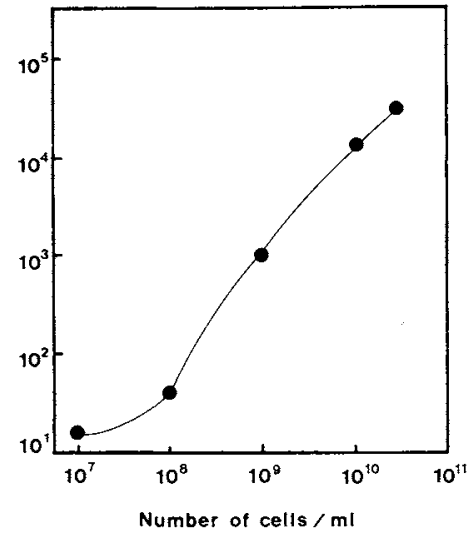

Fig. 1. Effects of Amount of DNA and Cell Concentration on Transformation Efficiency.

The number of transformants was investigated using B. flavum MJ233 and pCRY3.

(a) Effects of amount of DNA: Pen G (1 U/ml), HG buffer, cell concentration $\left(5 \times 10^{10} / \mathrm{ml}\right)$, and pulse field strength $(12.5 \mathrm{kV} / \mathrm{cm})$ were used at electroporation.

(b) Effects of cell concentration: Pen $\mathrm{G}(1 \mathrm{U} / \mathrm{ml}), \mathrm{HG}$ buffer, DNA amount $(1 \mu \mathrm{g})$, and pulse field strength $(12.5 \mathrm{kV} / \mathrm{cm})$ were used at electroporation.

ration buffers were examined. The optimal buffer to transform B. flavum MJ233 was $1 \mathrm{mM}$ HEPES-10\% glycerol buffer (pH 7.4).

4) Effects of amount of DNA and cell density. As shown in Fig. 1a, the number of transformants was increased by increasing of the amount of DNA from $20 \mathrm{ng}$ to $10 \mu \mathrm{g}$. Saturation was observed DNA above $1.0 \mu \mathrm{g}$. As shown in Fig. 1b, the number of transformants was increased by raising the cell concentration up to $5 \times 10^{10} \mathrm{cells} / \mathrm{ml}$.

Application of the electroporation method to various coryneform bacteria

As shown in Table IV, cured cells from $B$. lactofermentum ATCC 13869, C. glutamicum ATCC 31830, and B. stationis IFO 12144 were transformed with the plasmids, pAJ655, pCG4, and pCRY3, respectively. Each transformant was picked and examined for plasmid analysis. All colonies showed the same electrophoretic pattern of DNA as that of the respective plasmids.

In this report, we showed the electroporation as a novel efficient transformation method with plasmid DNA in intact cells, not only B. flavum MJ233 but also other coryneform bacteria.
Table IV. Application of Electroporation to VARIOUS CORYNEFORM BACTERIA

\begin{tabular}{lcc} 
Strains & Plasmid & $\begin{array}{c}\text { Number of } \\
\text { transformants }\end{array}$ \\
\hline $\begin{array}{c}\text { Brevibacterium } \\
\text { lactofermentum ATCC } 13869\end{array}$ & pAJ655 & $1.2 \times 10^{5 b}$ \\
$\begin{array}{l}\text { Brevibacterium } \\
\text { stationis IFO 12144 }\end{array}$ & pCRY3 & $1.7 \times 10^{3 \mathrm{c}}$ \\
$\begin{array}{c}\text { Corynebacterium } \\
\text { glutamicum ATCC } 31830\end{array}$ & pCG4 & $3.6 \times 10^{3 d}$ \\
\hline
\end{tabular}

a Electroporation was done at a cell concentration of $5 \times 10^{10} / \mathrm{ml}$, DNA amount of $1 \mu \mathrm{g}$, and a pulse field strength of $12.5 \mathrm{kV} / \mathrm{cm}$.

b Number of surviving cells after the pulse was $1.4 \times 10^{9}$.

c Number of surviving cells after the pulse was $0.7 \times 10^{9}$.

d Number of surviving cells after the pulse was $1.1 \times 10^{9}$.

Transformation of the auxotrophic mutant by the electroporation method

To confirm the possibility of using the electroporation method for selection of transformants using auxotrophic mutants, we constructed a plasmid, pCRY3-trp, which contained the tryptophan operon from the $E$. coli K-12 chromosome.

Electroporation was done as described in 
Materials and Methods, and minimal medium was used for selection of transformants. After 3 or 4 days of incubation, the transformants appeared. Because of using minimal medium, the appearance of colonies was delayed 1 or 2 days compared with transformants obtained on AR medium. However, the number of $\mathrm{Trp}^{+}$transformants was on a same order $\left(5 \times 10^{4} / \mu \mathrm{g}\right.$ DNA) to that of $\mathrm{Cm}^{\mathrm{r}}$ transformants. Also, we confirmed that deletion of plasmid pCRY3-trp in $\operatorname{Trp}^{+}$transformants did not occur.

All the above results suggest that intact cells can be used as host cells, therefore, auxotrophic complementation of transformation is made possible by high transformation efficiency, and this method is applicable to several types of coryneform bacteria so that it could become conventional for wide use in coryneform bacteria.

We believe that our method will lead to future progress in genetic studies.

\section{References}

1) S. Kinoshita, Appl. Microbiol., 1, 201 (1979).

2) K. Nakayama, S. Kitada and S. Kinoshita, J. Gen Appl. Microbiol., 7, 145 (1961).

3) M. Terasawa, H. Yukawa and Y. Takayama, Process Biochem., 20, 124 (1985).

4) H. Yukawa and M. Terasawa, Process Biochem., 21, 196 (1986).

5) H. Yukawa, H. Yamagata and M. Terasawa, Process Biochem., 21, 164 (1986).

6) R. Katsumata, A. Ozaki, T. Oka and A. Furuya, $J$. Bacteriol., 159, 306 (1984).

7) A. Ozaki, R. Katsumata, T. Oka and A. Furuya, Agric. Biol. Chem., 48, 2597 (1984).
8) G. R. Best and M. L. Britz, Appl. Microbiol. Biotechnol., 23, 288 (1986).

9) F. Sanchez, M. A. Penalva, C. Patino and V. Rubio, J. Gen. Microbiol., 132, 1767 (1986).

10) G. Thierbach, A. Schwarzer and A. Puhler, Appl. Microbiol. Biotechnol, 29, 356 (1988).

11) F. Tonaguzzo and A. Keating, Proc. Natl. Acad. Sci. U.S.A., 83, 3496 (1986).

12) N. M. Calvin and P. C. Hanawalt, J. Bacteriol., 170, $2796(1988)$

13) K. Ito, T. Nishida and K. Izaki, Agric. Biol. Chem., 52, 293 (1988).

14) J. F. Miller, W. J. Dower and L. S. Tomphins, Proc. Natl. Acad. Sci. U.S.A., 85, 856 (1988).

15) H. Wolf, A. Puhler and E. Neumann, Appl. Microbiol. Biotechnol, 30, 283 (1989).

16) J. S. Wolfson, D. C. Hooper, M. N. Swartz, M. D. Swartz and G. L. Mchugh, J. Bacteriol., 156, 1165 (1983).

17) H. Kase and K. Nakayama, Agric. Biol. Chem., 36, 1611 (1972)

18) H. C. Birnboim and J. Doly, Nucl. Acids Res., 7, 1513 (1979).

19) S. Takeshita, M. Sato, M. Toba, W. Masahashi and T. Goto, Gene, 61, 63 (1987).

20) Y. Satoh, K. Hatakeyama, K. Kohama, M. Kobayashi, Y. Kurusu and H. Yukawa, J. Indust. Microbiol., 5, 31 (1989).

21) H. Yukawa, Y. Kurusu, M. Shimazu, M. Terasawa, A. Ohta and I. Shibuya, Agric. Biol. Chem., 49, 3619 (1985).

22) M. Yoshihama, K. Higashiro, E. A. Rao, M. Akedo, W. G. Shanabruch, M. F. Follettie, G. C. Walker and A. J. Sinskey, J. Bacteriol., 162, 591 (1985).

23) I. Karube, E. Tamiya and H. Matsuoka, FEBS Lett., 182, 90 (1985).

24) H. Kaneko and K. Sakaguchi, Agric. Biol. Chem., 43 , 1007 (1979).

25) R. Santamaria, J. A. Gil, J. M. Mesas and J. F. Martin, J. Gen. Microbiol., 130, 2237 (1984).

26) K. Miwa, K. Matsui, M. Terabe, K. Ito, M. Ishida H. Takagi, S. Nakamori and K. Shiio, Gene, 39, 281 (1985). 